\title{
Genetic variability in Tambaqui generations of the breeding program in the Central-West Region of Brazil
}

\section{Variabilidade genética em gerações de Tambaqui do programa de melhoramento da Região Centro-Oeste do Brasil}

\author{
Angela Maria Urrea-Rojas ${ }^{1}$; Annaiza Braga Bignardi²; Felipe Pinheiro de Souza ${ }^{1}$; \\ Ed Christian Suzuki de Lima'; Denise Rocha Ayres²; Jayme Aparecido Povh; \\ Américo Moraes Neto ; Andrei Lincoln Yamachita5; Mariana Stucki Alves ${ }^{6}$; \\ Nelson Mauricio Lopera-Barrero ${ }^{7 *}$
}

\section{Highlights}

Preservation of genetic variability in the breeding program.

Deficit of heterozygotes in the G0 and $\mathrm{G} 2$ generations.

Positive inbreeding coefficient values in the G0 and G2 generations.

\begin{abstract}
The implementation of fish breeding programs in Brazil has brought significant results in the productivity of tilapia. However, the insertion of native species with great potential (such as Tambaqui Colossoma macropomum) in these programs is still recent, and thus requires genetic information for monitoring and enabling their consolidation into the programs. The objective of the present study was to evaluate the genetic diversity of the parental generation (G0) and two consecutive generations (G1 and G2) in the $C$. macropomum genetic improvement program, located in the municipality of Sorriso, Mato Grosso, Brazil.

1 Ph.D. Students at the Postgraduate Program in Animal Science, State University of Londrina, UEL, Londrina, PR, Brazil. E-mail: amur03013@gmail.com; felipeps1991@gmail.com; edchris7@hotmail.com

2 Profas Dras, Institute of Agricultural and Technological Sciences, Federal University of Rondonópolis, UFR, Rondonópolis, MT, Brazil. E-mail: bignardi@ufr.edu.br; denise.ayres@ufr.edu.br

3 Prof. Dr., Faculty of Veterinary Medicine and Animal Science, Federal University of Mato Grosso do Sul, UFMS, Campo Grande, MS, Brazil. E-mail: jayme.povh@ufms.br

4 Student at the graduate in Animal Science, Faculty of Veterinary Medicine and Animal Science, Federal University of Mato Grosso do Sul, UFMS, Campo Grande, MS, Brazil. E-mail: netoamerico@gmail.com.

5 Ph.D. Student at the Postgraduate Program of Biotechnology, UEL, Londrina, PR, Brazil. E-mail: andreilincoln16@gmail. com

6 Student at the Institute of Agricultural and Technological Sciences, Federal University of Rondonópolis, UFR, Rondonópolis, MT, Brazil. E-mail: marianastucki@gmail.com.

7 Prof. Dr., Department of Animal Science and Postgraduate Program in Animal Science, UEL, Londrina, PR, Brazil. E-mail: nmlopera@uel.br

* Author for correspondence
\end{abstract}

Received: Sept. 07, 2020 - Approved: Feb. 26, 2021 
Ninety caudal fin samples were collected (30 samples per generation) for DNA extraction. The genetic study implemented seven microsatellite markers (Cm1A8, Cm1A11, Cm1D1, Cm1E3, Cm1F4, Cm1F5, and $\mathrm{Cm} 1 \mathrm{H} 8$ ). A total of 17 alleles were amplified, with variations in the mean number between four to two alleles per locus. The size per locus ranged from 170 to $360 \mathrm{bp}$. The average inbreeding coefficient was 0.126 (G0), -0.040 (G1), and 0.131 (G2). No null or exclusive alleles were found. The observed heterozygosity values for $\mathrm{G} 1$ and $\mathrm{G} 2$ demonstrated the preservation of genetic variability ( 0.453 and 0.409 , respectively). In conclusion, the genetic diversity of the parental generation (G0) and the two progenies generations (G1 and G2) were adequate, which demonstrates that the genetic improvement program was conducted correctly; however, it is important to continue to evaluations the genetic diversity of the future progeny.

Key words: Colossoma macropomum. Native species. Genetic improvement. Microsatellites.

\section{Resumo}

A implantação de programas de melhoramento genético de peixes do Brasil tem trazido resultados significativos na produtividade de peixes como na Tilápia. No entanto, a inserção desses programas em espécies nativas de grande potencial como o Tambaqui (Colossoma macropomum) ainda é recente, sendo necessárias informações genéticas que permitam seu monitoramento e viabilizem sua consolidação. $O$ objetivo do presente estudo foi avaliar a diversidade genética da geração parental (G0) e duas gerações consecutivas ( $\mathrm{G} 1$ e $\mathrm{G} 2$ ) do programa de melhoramento genético de Colossoma macropomum, localizado no município de Sorriso Mato Grosso, Brasil. Noventa amostras de nadadeira caudal foram coletadas (30 amostras por geração) para a extração do DNA. O estudo genético foi conduzido implementando-se um total de sete loci microssatélites (Cm1A8, Cm1A11, Cm1D1, Cm1E3, Cm1F4, Cm1F5 e Cm1H8). Um total de 17 alelos foram amplificados, com variações no número médio entre quatro a dois alelos por locus. O tamanho por loci variou entre 170 a 360 pares de bases. O coeficiente de endogamia médio foi 0,126 (G0), -0,040 (G1) e 0,131 (G2). Não foram encontrados alelos nulos nem alelos exclusivos. Os valores de heterozigosidade observada para G1 e G2 demonstraram preservação da variabilidade genética (0,453 e 0,409, respectivamente). Em conclusão a diversidade genética tanto da geração parental (G0) como das duas gerações (G1 e G2) foi adequada, o que demostra que o programa de melhoramento genético está sendo conduzido de maneira correta sendo importante dar continuidade com avaliações de diversidade genética nas progênies futuras.

Palavras-chave: Colossoma macropomum. Espécie nativa. Melhoramento genético. Microssatélites.

\section{Introduction}

In 2019, Brazilian fish farming reached a total fish production of 758,006 tons, $4.9 \%$ higher than the previous year (Peixe BR, 2020). Of this total, Nile tilapia (Oreochromis niloticus) represented approximately $57 \%$ of the total production with 432,149 tons, while the production of native fish was $38 \%$, of which
287,930 tons were Tambaqui (Colossoma macropomum) (Peixe BR, 2020). Much of the success of tilapia production is due to the implementation of genetic improvement programs; tools such as selection and crossing are used for the formation of the following generations, with the aim of increasing weight gain (Ribeiro \& Legat, 2008). These programs become even more important when 
they maximize the use of physical space by improving the rate of growth, survival, and feed conversion of target species (Gjedrem, Robinson, \& Rye, 2012). Despite all the success achieved with tilapia, breeding programs for native species are still scarce and are currently in the early stages of development. Tambaqui is highly valued due to its ease of cultivation, easy reproduction, high commercial value, and high zootechnical performance (Araujo-Lima \& Goulding, 1997; Mello et al., 2015), and is now widespread in fish farms in several regions of Brazil and in South America. In 2008, the first Tambaqui genetic improvement program was implemented in the state of Mato Grosso (MT), with families selected for weight gain from different Brazilian fish farms (Marcos et al., 2016). Since then, three generations have been obtained from the crossing between these individuals.

Because mating is aimed at the superior performance of the progeny, there is a clear concern regarding the genetic diversity of the generations that are developed by the breeding programs. Studies with improved Nile tilapia have revealed the importance of assessing genetic diversity in order to control inbreeding depression in herds and strains (Petersen et al., 2012; Rodriguez-Rodriguez et al., 2013). Recent studies have also highlighted this concern with stocks of Tambaqui breeders (Lopera-Barrero et al., 2015; Ribeiro et al., 2016; Santos, Santana, Leitão, Paula-Silva, \& AlmeidaVal, 2016; Aguiar et al., 2018). Therefore, methodologies that allow the genetic characterization of these animals are essential, and molecular markers such as microsatellites can act in this evaluation, as they are capable of providing several important genetic parameters (Abdul-Muneer, 2014), assisting with measures of reproductive management and improvement or conservation programs (Santos et al., 2016; Aguiar et al., 2018; Souza et al., 2018). Therefore, genetic monitoring of the base population (coming from the crossing of populations of different origins), together with monitoring subsequent generations of these programs, and also the breeding and distribution stations of the fry, is essential to determine the possible effects of drift, inbreeding, or selection (Petersen et al., 2012) and to direct actions in these programs. Thus, the objective of the present study was to evaluate the genetic diversity of the parental generation (G0) and two consecutive generations ( $G 1$ and $G 2$ ) of the genetic improvement program of Tambaqui carried out in the state of MT, Brazil.

\section{Material and Methods}

The study was approved by the Ethics Committee of the State University of Londrina (CEUA_UEL No. 10689.2018.08). A total of 90 caudal fin samples (approximately $0.5 \mathrm{~cm}^{2}$ ) were collected from three generations of Tambaqui (30 samples per generation) generated by the genetic improvement program in the municipality of Sorriso, MT, Brazil. The selected individuals were part of the native fish genetic improvement program (targeted for weight gain), which started in 2008, with Tambaqui as the chosen species. The first generation (G1) was formed during the reproductive period of $2011 / 2012$. The second-generation (G2) was obtained in the reproductive year of 2015. At the time of collecting the fin sample (using sanitized surgical scissors), the individuals were immobilized through wet towels that reduced stress. The samples were conditioned in microtubes containing $70 \%$ ethanol, and were used in the laboratory analysis. For the 
DNA extraction, the $\mathrm{NaCl}$ extraction protocol was used (Lopera-Barrero et al., 2008). To assess the total DNA concentration, the samples were measured using the SLIPQ 026 spectrophotometer, Quantifier L-Quant (Loccus Biotecnologia, Ribeirão Preto, Brazil). The samples were diluted to a concentration of $30 \mathrm{ng} / \mu \mathrm{L}$. The DNA integrity was assessed on a $1 \%$ agarose gel, stained with SYBR Safe тм DNA Gel Stain for one hour at 90 V. The gel was visualized in a transilluminating device with ultraviolet light, and the image was photographed using the Kodak EDAS program (1D Image Analysis 3.5 Kodak, USA).

The DNA was amplified to a final reaction volume of $15 \mu \mathrm{l}$ using $1 \mathrm{X} \times$ Tris- $\mathrm{KCl}$ buffer, $2.0 \mu \mathrm{l} \mathrm{MgCl} 2,0.4 \mu \mathrm{l}$ of each primer (Forward and Reverse), $0.2 \mu \mathrm{l}$ of each dNTP, a unit of Platinum Taq DNA Polymerase, and $60 \mathrm{ng}$ of DNA from each animal. Seven species-specific microsatellite primers from Santos, Hrbek and Farias (2009) were amplified: Cm1 A8, Cm1A11, Cm1D1, Cm1E3, Cm1F4, Cm1F5, and Cm1H8. Initially, the DNA was denatured at $94^{\circ} \mathrm{C}$ for $4 \mathrm{~min}$ and then 30 cycles were performed, each consisting of $1 \mathrm{~min}$ of denaturation at $94^{\circ} \mathrm{C}, 1 \mathrm{~min}$ of annealing (the temperature being variable for each primer), and $1 \mathrm{~min}$ of extension at $72^{\circ} \mathrm{C}$. After that, a final extension was performed at $72^{\circ} \mathrm{C}$ for $10 \mathrm{~min}$. The reactions were conducted in a Veriti ${ }^{\circledR}$ thermal cycler (Applied Biosystems ${ }^{\circledR}$, Austin, TX, USA). The amplified samples were subjected to $10 \%$ polyacrylamide gel electrophoresis, conducted in $0.5 \mathrm{X}$ TBE buffer at $180 \mathrm{~V}$ and $250 \mathrm{~mA}$ for $8 \mathrm{~h}$. Subsequently, nitrate staining was performed to visualize the microsatellite alleles. The gel was photo-documented and submitted to the Adobe Photoshop CC (64 Bit) program, where it was aligned and the alleles were calculated using a $100 \mathrm{bp}$ DNA ladder. The number of alleles, allele frequency, allele wealth (Ra), and inbreeding coefficient (FIS) were calculated using the FSTAT 2.9.3 program (Goudet, 2005), applying the Bonferroni correction to evaluate the significance $(P<0$ 05). The expected heterozygosis $(\mathrm{He})$, observed heterozygosis (Ho), and Hardy-Weinberg equilibrium test (HWE, $\mathrm{P}<0.05$ ) were estimated using the Arlequin 3.5 program (Excoffier, Laval, \& Schneider, 2010). The number of effective alleles $(\mathrm{Ne})$ was calculated for each locus using the GenAlex program version 6.5 (Peakall \& Smouse, 2012). The possible reduction in the effective size of the generations was verified with the program Bottleneck 1.2.02 (Cornuet \& Luikart, 1996), considering the mutation models: IAM (Infinite Allele Model), TPM (TwoPhase mutation Model), and SMM (Stepwise Mutation Model). Statistical significance was assessed using the Wilcoxon test, with a significance level of $5 \%$.

The STRUCTURE v.2.3.3 by Pritchard, Stephens and Donnelly (2000) was used to verify the existence of clusters $(K)$ of genetically similar samples, following the mixed model of clusters with burning 250,000 Markov and Monte Carlo (MCMC) chains and a running length of 1,000,000 MCMC. The $\mathrm{K}$ estimates (number of clusters) were obtained from simulations performed with $\mathrm{K}$ ranging from one to six ( $K=1-6)$, reproducing 10 interactions for each tested $K$ value. The number of clusters was determined by the method proposed by Evanno Regnault and Goudet (2005), implemented on the website Structure Harvester Earl and Vonholdt (2012). The factorial correspondence analysis (FCA) based on the allele frequencies was elaborated by the GENETIX software version 4.05 (Belkhir, Borsa, Chikhi, Raufaste, \& Bonhomme, 2004). 


\section{Results and Discussion}

A total of 17 alleles were found for $\mathrm{GO}$ and $\mathrm{G} 1$ and 16 alleles for $\mathrm{G} 2$, ranging from 170 to $360 \mathrm{bp}$. The allelic richness (Ra) and the number of effective alleles $(\mathrm{Ne})$ ranged from 2.0 to 4.0 and 1.824-1.893, respectively, and were maintained across generations. No exclusive or limiting alleles were found. However, the Cm1D11 locus in G2 showed a loss in the $178 \mathrm{bp}$ allele. This loss can be attributed to variations in the ringing regions of the primers, which is a very common situation in microsatellite markers (Rodriguez-Rodriguez et al., 2013). The mean values found for the $\mathrm{Ho}$, when compared to the He, showed that there was a deficit in the number of heterozygotes in the parental generation G0 (-0.056), with an excess of heterozygotes in the first generation G1 (0.017) and a deficit of heterozygotes in the second-generation G2 (-0.061). These results were corroborated by the FIS inbreeding coefficient, in which the mean values were positive for G0 (0.126) and G1 (0.131), and negative for G2 $(-0.140)$. There was no significant difference in the mean values in the Hardy-Weinberg equilibrium test (Table 1). The deficit of heterozygotes in the parental generation may be correlated to the limited number of families (individuals) implemented to form the following generations.

One of the main factors in the loss of genetic variability in fish farming is the founding effect, but it is not the only one. Other factors, such as the bottleneck effect, are caused by unintentional selection during the reproductive processes performed. These processes, which normally include the selection of individuals with the best phenotypic or reproductive characteristics, can lead to mating between genetically related individuals and generate the loss of variability (Aguiar et al., 2018; Santos et al., 2016; Jacometo et al., 2010). Even with the possibility that these effects are still present in the breeding program, we cannot affirm that they have affected the frequencies, since the reproductive management information of the families employed at the beginning of the program was not counted and their origin was not available. 
Table 1

Number of alleles per locus ( $\mathrm{Na}$ ), allele richness (Ra), Effective alleles (Ne), Observed (Ho) and expected (He) heterozygosity, Hardy-Weinberg Equilibrium Test (HWE) and Inbreeding coefficient (FIS) for generations of Colossoma macropomum

\begin{tabular}{|c|c|c|c|c|c|c|c|c|}
\hline Gerações & Locus & $\mathrm{Na}$ & $\mathrm{Ra}$ & $\mathrm{Ne}$ & Ho & $\mathrm{He}$ & HWE & FIS \\
\hline \multirow{8}{*}{ G0 } & Cm1A8 & 4.000 & 4.000 & 2.920 & 1.000 & 0.670 & $0.000^{*}$ & -0.506 \\
\hline & $\mathrm{Cm} 1 \mathrm{~A} 11$ & 2.000 & 2.000 & 1.708 & 0.103 & 0.421 & $0.000^{*}$ & 0.758 \\
\hline & Cm1D1 & 3.000 & 3.000 & 2.116 & 0.448 & 0.536 & 0.344 & 0.167 \\
\hline & Cm1E3 & 2.000 & 2.000 & 1.906 & 0.185 & 0.484 & $0.002^{*}$ & 0.622 \\
\hline & Cm1H8 & 2.000 & 2.000 & 1.897 & 0.366 & 0.480 & 0.251 & 0.240 \\
\hline & Cm1F4 & 2.000 & 2.000 & 1.122 & 0.115 & 0.110 & 1.000 & -0.042 \\
\hline & Cm1F5 & 2.000 & 2.000 & 1.824 & 0.551 & 0.459 & 0.413 & -0.204 \\
\hline & Média & 2.429 & 2.429 & 1.927 & 0.395 & 0.451 & 0.287 & 0.126 \\
\hline \multirow{8}{*}{ G1 } & $\mathrm{Cm} 1 \mathrm{~A} 8$ & 4.000 & 4.000 & 2.715 & 0.966 & 0.642 & $0.000^{*}$ & -0.518 \\
\hline & $\mathrm{Cm} 1 \mathrm{~A} 11$ & 2.000 & 2.000 & 1.976 & 0.444 & 0.503 & 0.698 & 0.119 \\
\hline & Cm1D1 & 3.000 & 3.000 & 1.911 & 0.481 & 0.485 & 0.445 & 0.009 \\
\hline & Cm1E3 & 2.000 & 2.000 & 1.554 & 0.321 & 0.362 & 0.603 & 0.116 \\
\hline & Cm1H8 & 2.000 & 2.000 & 1.649 & 0.307 & 0.401 & 0.318 & 0.237 \\
\hline & Cm1F4 & 2.000 & 2.000 & 1.523 & 0.280 & 0.350 & 0.551 & 0.204 \\
\hline & Cm1F5 & 2.000 & 2.000 & 1.438 & 0.375 & 0.311 & 0.551 & -0.211 \\
\hline & Média & 2.429 & 2.429 & 1.824 & 0.453 & 0.436 & 0.452 & -0.040 \\
\hline \multirow{8}{*}{ G2 } & Cm1A8 & 4.000 & 4.000 & 2.903 & 1.000 & 0.666 & $0.000^{*}$ & -0.513 \\
\hline & Cm1A11 & 2.000 & 2.000 & 1.787 & 0.241 & 0.448 & $0.028^{*}$ & 0.466 \\
\hline & Cm1D1 & 2.000 & 2.000 & 1.998 & 0.344 & 0.508 & 0.134 & 0.325 \\
\hline & Cm1E3 & 2.000 & 2.000 & 1.471 & 0.400 & 0.326 & 0.541 & -0.231 \\
\hline & Cm1H8 & 2.000 & 2.000 & 1.536 & 0.350 & 0.357 & 1.000 & 0.022 \\
\hline & Cm1F4 & 2.000 & 2.000 & 1.976 & 0.148 & 0.503 & $0.000^{*}$ & 0.709 \\
\hline & Cm1F5 & 2.000 & 2.000 & 1.899 & 0.384 & 0.482 & 0.408 & 0.206 \\
\hline & Média & 2.286 & 1.938 & 1.983 & 0.409 & 0.470 & 0.301 & 0.131 \\
\hline
\end{tabular}

G0: Parental generation; G1: First generation; G2: Second generation.

${ }^{*} \mathrm{P}<0.05$ : significant in the Hardy-Weinberg Equilibrium Test.

In genetic improvement programs, positive $F_{\text {IS }}$ values are expected, since the intensity of selection can cause genetic drift by reducing the effective size of the population, caused by the recombination of the selected progenies (Rodriguez-Rodriguez et al., 2013). Therefore, the decrease in genetic variability in these programs can occur (R. C. Gonçalves \& Oliveira, 2009) due to the genetic bottleneck caused by the selection process. However, it is noteworthy that this reduction was not significant to the point of generating inbreeding within each generation. On the contrary, the Ho values for $\mathrm{G} 1$ and $\mathrm{G} 2$ demonstrated the 
preservation of genetic variability $(0.453$ and 0.409 , respectively), which were even comparable with populations from Tambaqui with a deficit of heterozygotes (Santana, 2011). The results of the present study were similar to other studies on the genetic diversity in natural and captive populations of Tambaqui. Santos et al. (2016) analyzed their genetic diversity by amplifying 13 microsatellite loci from three stock populations (Balbina, UFRPE, and DNOCS) and a natural population (River Solimões, Amazonas) and found Ho values of $0.52,0.26,0.51$, and 0.53 , He values of 0.63 , $0.48,0.55$, and 0.79 , and $F_{\text {IS }}$ values of 0.18 , $0.46,0.07$, and 0.33 for the three stock and one natural population, respectively. The authors concluded that the genetic diversity of the natural population was greater than that of the stock populations, which is an important genetic resource for future breeding programs.

On the other hand, Aguiar et al. (2018) amplified 12 microsatellite loci and analyzed the genetic diversity in populations and stocks located in Santarém (STM), Ouro Preto do Oeste (OPO), Nossa Senhora do Livramento (NSL), Jaguaribara (JAG), Pentecostes (PEN), Neópolis (NPL), Jaboticabal (JAB), and a natural population in the Amazon River (AMA). The authors observed that five of the breeding sites showed excess heterozygotes for six or more microsatellite loci, with negative mean FIS values or values close to zero. These stocks were NSL $\left(F_{1 S}=0.169\right), J A G\left(F_{1 S}=0.180\right)$, PEN $\left(F_{\text {IS }}=0.030\right)$, NPL (FIS $\left.=0.050\right)$, and JAB $(F / S=0.056)$. However, they found that three stocks showed a deficit of heterozygotes for most of the loci and with average $F_{\text {IS }}$ values of 0.099 (STM), 0.149 (OPO), and 0.106 (AMA). The results of this study indicated that some of the captive stocks analyzed may have been suffering from the effects of inbreeding depression, or were at least in the early stages of that process. The value of $\mathrm{He}$ (excess of heterozygotes) was greater than that of Hd (deficiency of heterozygotes), which indicated that the generations suffered from a recent bottleneck effect (Table 2). In fish farms, the bottleneck effect occurs due to the intentional selection and mating between possibly related individuals, in addition to the limited number of couples that constitute all the following generations, which may occur in breeding programs (Rodriguez-Rodriguez et al., 2010, 2013; Lopera-Barrero et al., 2015). In the specific case of a genetic improvement program, because of the intentional selection that is necessary to target mating in terms of producing the characteristic that requires improvement, a bottleneck effect is expected. However, in fish farms, the loss of genetic variability can also be related to the founding effect, which increases the genetic drift. The increased genetic drift then increases homozygosity and the occurrence of inherited diseases. To counteract the effects of genetic drift, it is necessary to increase the gene flow between isolated fish farms to restore the genetic variation within each population (Gonçalves, Santos, Sá Leitão, Souza, \& Almeida Val, 2019). 
Table 2

Bottleneck effect in the G0, G1 and G2 generations of Colossoma macropomum

\begin{tabular}{cccccccc} 
Geração & $\mathrm{N}$ & $\mathrm{IAMa}$ & \multicolumn{3}{c}{$\mathrm{TMMb}$} \\
$\mathrm{G}$ & & $\mathrm{Hd} / \mathrm{He}$ & $\mathrm{P}$ & $\mathrm{Hd} / \mathrm{He}$ & $\mathrm{P}$ & $\mathrm{Hd} / \mathrm{He}$ & $\mathrm{P}$ \\
G1 & 30 & $1 / 6$ & $0.015^{*}$ & $1 / 6$ & $0.023^{*}$ & $1 / 6$ & $0.039^{*}$ \\
G2 & 30 & $0 / 7$ & $0.007^{*}$ & $0 / 7$ & $0.007^{*}$ & $1 / 6$ & $0.015^{*}$ \\
\hline
\end{tabular}

G0: Parental generation; G1: First generation; G2: Second generation.

$\mathrm{N}$ : Number of individuals per population

a: The Infinite Allele Model; b: Two-phase Mutation Model; c: Stepwise Mutation Model

* Significant values by the Wilcoxon test $(P<0.05)$.

The results of the Bayesian analysis for the model show that the ideal Delta $-\mathrm{K}$ value corresponded to $K=2$, indicating the existence of two clusters and mixing in the individuals of the three generations (Figure 1). All generations were related by their allele frequencies, an expected result because these two groups originated from the initial generation (GO) and were maintained through the following generations ( $G 1$ and $G 2$ ). In the FCA, most individuals of the generations were in the middle of $A \times 1$ and $A \times 2$, with an association between individuals over the generations (Figure 2). Regarding the allelic distribution in the individuals, it was possible to observe a conservation of frequencies throughout the generations, demonstrating that the breeding program does not follow any trend and is being conducted correctly; however, it is important to continue evaluating the generations. It should also be emphasized that through quantitative analyses supported by qualitative analyses, the allelic distribution can be controlled, avoiding the increase of inbreeding and loss of genetic variability in the populations. It is important to note that the continuous monitoring of fish populations in both conservation and production programs is important to avoid decreasing the genetic variability, which has led to problems such as low rates of growth, survival, and adaptability (Jacometo et al., 2010). The speed of this decline is influenced by reproductive management, parental changes, selection, the number of parents used in mating, and implementing the reproductive system (Lopera-Barrero et al., 2015).

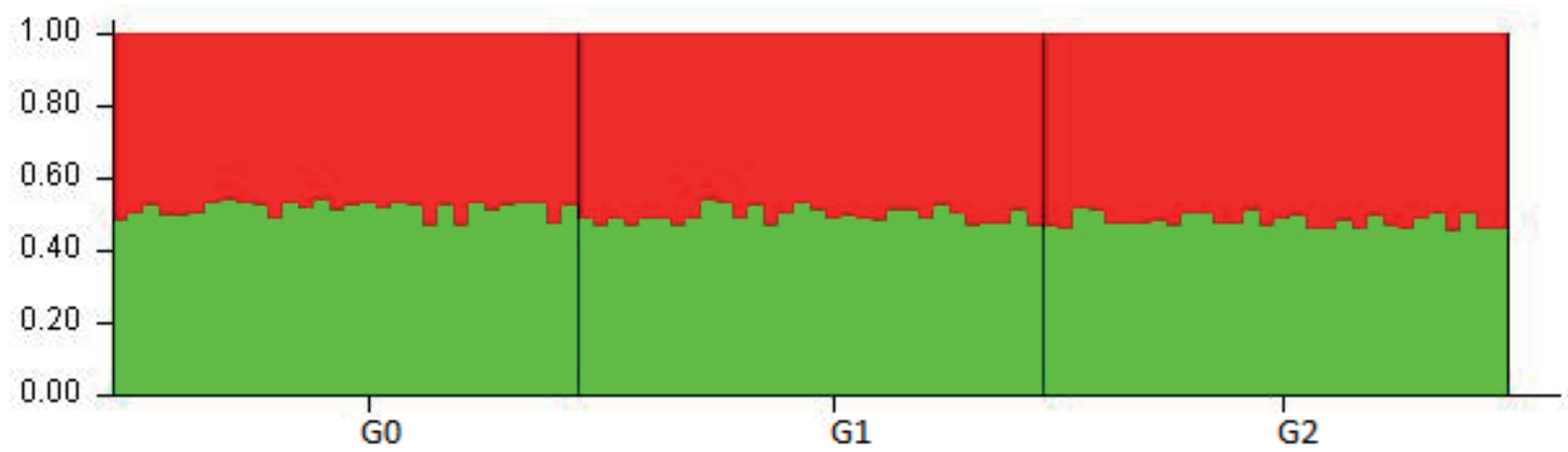

Figure 1. Bayesian cluster analysis based on the seven microsatellite loci for the G0, G1 and G2 generations of Colossoma macropomum, indicating a Delta- $\mathrm{K}$ value ( $\mathrm{K}=2)$. $\mathrm{G0}$ : Parental generation; G1: First generation; G2: Second generation. 


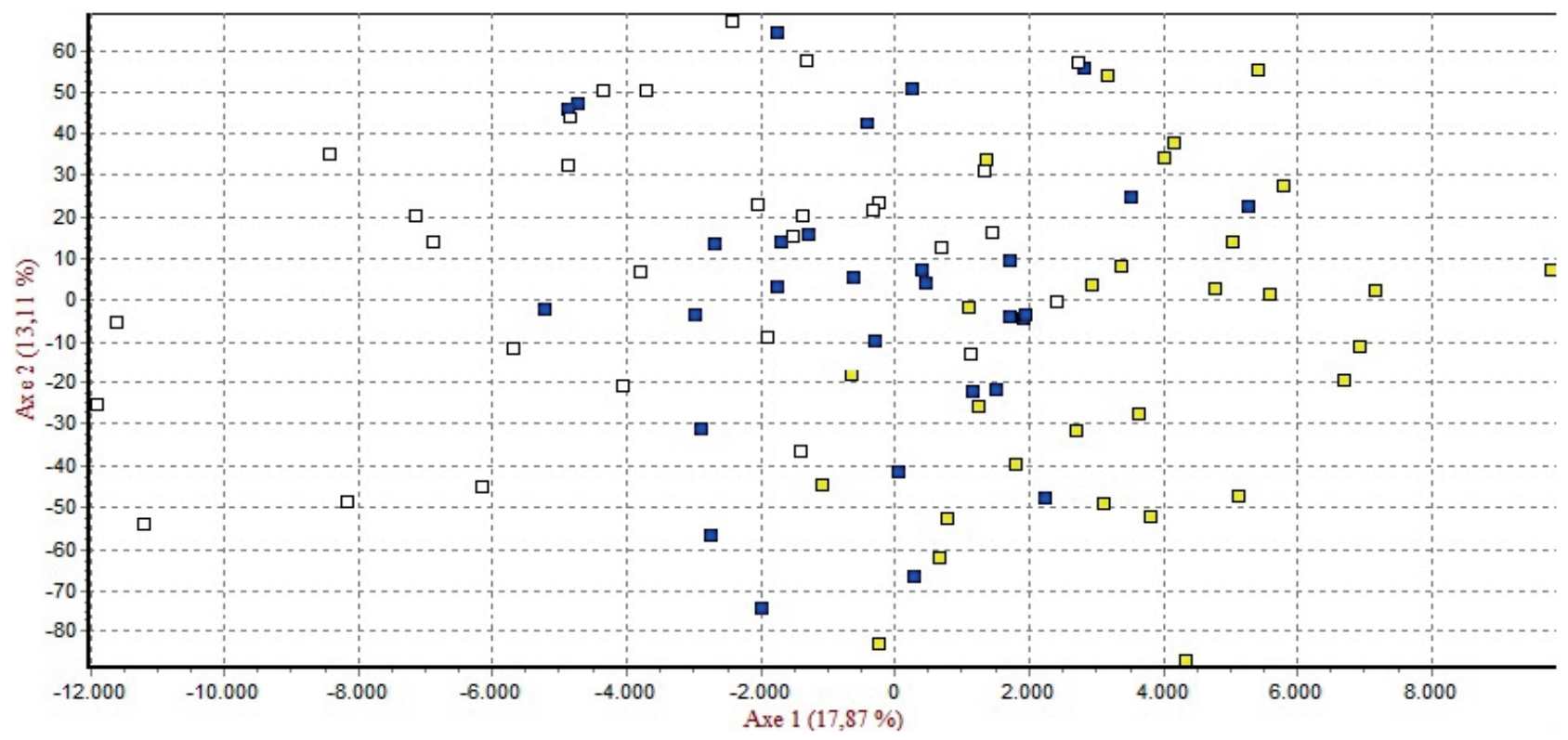

Figure 2. Factor component analysis (FCA), showing the distribution of spatial variation in the G0, $\mathrm{G} 1$ and $\mathrm{G} 2$ generations of Colossoma macropomum. Yellow squares = G0, blue squares = G1 and white squares $=\mathrm{G} 2$.

One way of evaluating the impacts caused by inbreeding is through the evaluation of parameters such as fertility levels and the survival rate of the progeny, as well as their growth and adaptation to the environment. This will ensure the renewal of stock through the introduction of individuals captured from nature or other fish farms will only occur when necessary to increase heterozygosity and reduce the loss of genetic diversity in cultivated populations (Aguiar et al., 2018).

The results of this study are an important source of information for the Tambaqui genetic improvement program, as well as for fish breeders and researchers in managing reproductive stocks and conservation.

\section{Conclusions}

The genetic diversity of both the parental generation (G0) and the two generations (G1 and G2) was adequate, which shows that the genetic improvement program located in the municipality of Sorriso, MT, Brazil is being conducted correctly. However, it is important to continue assessing the genetic diversity of future progenies.

\section{Acknowledgments}

The authors would like to thank the "Conselho Nacional de Desenvolvimento Científico e Tecnológico (CNPq)", the "Coordenação de Aperfeiçoamento de Pessoal de Nível Superior" (CAPES), and the "Programa de Pós Graduação em Ciência Animal (Universidade Estadual de Londrina)" for scholarships and financial support. 


\section{References}

Abdul-Muneer, P. M. (2014). Application of microsatellite markers in conservation genetics and fisheries management: recent advances in population structure analysis and conservation strategies. Genetics Research International, 2014, 691759. doi: 10.1155/2014/691759

Aguiar, J. D. P., Gomes, P. F. F., Hamoy, I. G., Santos, S. E. B. D., Schneider, H., \& Sampaio, I. (2018). Loss of genetic variability in the captive stocks of tambaqui, Colossoma macropomum (Cuvier, 1818), at breeding centers in Brazil, and their divergence from wild populations. Aquaculture Research, 49(5), 1914-1925. doi: 10.1111/are.13647

Araujo-Lima, C. A. R. M., \& Goulding, M. (1997). So fruitful fish: ecology, conservation, and aquaculture of the Amazon's Tambaqui. New York: Columbia University Press.

Belkhir, K., Borsa, P., Chikhi, L., Raufaste, N., \& Bonhomme, F. (2004). Genetix 4.05, logiciel sous Windows TM pour la genetique des populations. Montpellier, France: Laboratoire Genome, Populations, Interactions, CNRS UMR 5000, Universite de Montpellier II.

Cornuet, J. M., \& Luikart, G. (1996). Description and power analysis of two tests for detecting recent population bottlenecks from allele frequency data. Genetics, 144(4), 2001-2014.

Earl, D. A., \& Vonholdt, B. M. (2012). Structure Harvester: a website and program for visualizing Structure output and implementing the Evanno method. Conservation Genetic Research, 4(2), 359361. doi: 10. 1007/s12686-011-9548-7
Evanno, G., Regnault, S., \& Goudet, J. (2005). Detecting the number of clusters of individuals using the software structure: a simulation study. Molecular Ecology, 14(8), 2611-2620. doi: 10.1111/j.1365294X.2005.02553.x

Excoffier, L., Laval, G., \& Schneider, S. (2005). Arlequin ver. 3.0: An integrated software package for population genetics data analysis. Evolution Bioinformatics Online, 11(1), 47-50. doi: 10.1177/11769343050 0100003

Gjedrem, T., Robinson, N., \& Rye, M. (2012). The importance of selective breeding in aquaculture to meet future demands for animal protein: a review. Aquaculture, 350(353), 117 129. doi: 10.1016/j.aqua culture.2012.04.008

Gonçalves, R. A., Santos, C. H. D. A. D., Sá Leitão, C. S. de, Souza, É. M. S. de, \& Almeida Val, V. M.F.de. (2019). Genetic basis of Colossoma macropomum broodstock: perspectives for an improvement program. Journal of the World Aquaculture Society, 50(3), 633644. doi: 10.1111/jwas.12564

Gonçalves, R. C., \& Oliveira, L. C. (2009). EMBRAPA Acre: ciência e tecnologia para o desenvolvimento sustentável do Sudoeste da Amazônia. Rio Branco, AC: EMBRAPA Acre.

Goudet, J. (2005). FSTAT: a program to estimate and test gene diversities and fixation indices (version 2.9.3.2). Retrieved from https://www2.unil.ch/popgen/softwares/ fstat.htm

Jacometo, C. B., Barrero, N. M. L., RodriguezRodriguez, M. D. P., Gomes, P. C., Povh, J. A., Streit, D. P., Jr.,... Ribeiro, R. P. (2010). Variabilidade genética em tambaquis (Teleostei: Characidae) de diferentes 
regiões do Brasil. Pesquisa Agropecuária Brasileira, 45(5), 481-487. doi: 10.1590/ S0100-204X201000 0500007

Lopera-Barrero, N. M., Povh, J. A., Ribeiro, R. P., Gomes, P. C., Jacometo, C. B., \& Lopes, T. S. (2008). Comparison of DNA extraction protocols of fish fin and larvae samples: modified salt $(\mathrm{NaCl})$ extraction. Ciencia e Investigación Agraria, 35, 65-74. doi: 10.4067/S0718-16202008000100008

Lopera-Barrero, N. M., Rodriguez-Rodriguez, M. D. P., Fornari, D. C., Resende, E. K., PovedaParra, A. R., Braccini, G. L.,... Ribeiro, R. P. (2015). Genetic variability of broodstocks of Tambaqui (Teleostei: Characidae) from the northeast region of Brazil. Semina: Ciências Agrárias, 36(6), 4013-4022. doi: 10. 5433/1679-0359.2015v36n6p4013

Marcos, R.; Povh, J. A.; Fornari, D. C.; De Oliveira, C. A. L.; Ribeiro, R. P.; Lopera-Barrero, N. M.; Murari, P. J. F. (2016). Weight gain and morphometric growth of genetically improved Tambaqui (Colossoma macropomum). Semina: Ciências Agrárias, 37(4), 2521-2527. doi: 10.5433/1679-03 59.2016v37n4 Supl1p2521

Mello, F., Oliveira, C. A. L., Ribeiro, R. P., Resende, E. K., Povh, J. A., Fornari, D. C.,... Streit, D., Jr. (2015). Growth curve by Gompertz nonlinear regression model in female and males in tambaqui (Colossoma macropomum). Anais da Academia Brasileira de Ciências, 87(4), 2309-2315. doi: 10.1590/ 0001-3765201520140315

Peakall, R., \& Smouse, P. E. (2012). GenALEx 6.5: Genetic analysis in Excel. Population genetic software for teaching and research-an update. Bioinformatics, 28(19), 2537-2539. doi: 10.1093/bioinfor matics/ bts 460
Peixe BR: Associação Brasileira da Piscicultura (2020). Anuário Peixe BR da Piscicultura 2019. São Paulo.

Petersen, R. L., Garcia, J. E., Mello, G., Liedke, A. M. R., Sincero, T. C. M., \& Grisard, E. C. (2012). Análise da diversidade genética de tilápias cultivadas no estado de Santa Catarina (Brasil) utilizando marcadores microssatélites. Boletim do Instituto de Pesca, 38(4), 313-321.

Pritchard, J. K., Stephens, M., \& Donnelly, P. (2000). Inference of population structure using multilocus genotype data. Genetics, 155(2), 945-959.

Ribeiro, R. P., \& Legat, A. P. (2008). Delineamento de programas de melhoramento genético de espécies aqüícolas no Brasil. Teresina: EMBRAPA Meio-Norte (INFOTECA-E).

Ribeiro, R. P., Rodriguez-Rodriguez, M. P., Resende, E. K., Souza, F. P., Povh, J. A., Poveda-Parra, A. R.,... Lopera-Barrero, N. M. (2016). Genetic characteristics of Tambaqui broodstocks in the state of Rondônia, Brazil: implications on production and conservation. Semina: Ciências Agrárias, 37(4), 2375-2386. doi: 10.5433/1679-03 59.2016v37n4Supl1p2375

Rodriguez-Rodriguez, M. D. P., Lopera-Barrero, N. M., Ribeiro, R. P., Povh, J. A., Vargas, L., \& Sirol, R. N. (2010). Diversidad genética de piracanjuba usada en programas de repoblación con marcadores microsatélites. Pesquisa Agropecuária Brasileira, 45(1), 56-63. doi: 10.1590/S01 00-204X2010000100 008

Rodriguez-Rodriguez, M. D. P., Lopera-Barrero, N. M., Vargas, L., Albuquerque, D. M., Goes, E. S. R., Prado, O. P. P., \& Ribeiro, R. P. (2013). Caracterização genética de gerações 
de tilápia Gift por meio de marcadores microssatélites. Pesquisa Agropecuária Brasileira, 48(10), 1385-1393. doi: 10.1590 IS0100-204X2013001000010

Santana, G. X. (2011). Marcadores microssatélites: ferramentas para manejo e conservação da variabilidade genética em populações de tambaqui (Colossoma macropomum, Cuvier 1818). Tese de doutorado, Genética, Conservação e Biologia Evolutiva, GCBEv, Instituto Nacional de Pesquisas da Amazônia Manaus, AM, Brasil.

Santos, C. H. A., Santana, G. X., Leitão, C. S., Paula-Silva, M. N., \& Almeida-Val, V. M. F. (2016). Loss of genetic diversity in farmed populations of Colossoma macropomum estimated by microsatellites. Animal Genetics, 47(3), 373-376. doi: 10.1111/ age. 12422
Santos, M. C. F., Hrbek, T., \& Farias, I. (2009). Microsatellite markers for the tambaqui (Colossomamacropomum, Serrasalmidae, Characiformes), an economically important 20 keystone species of the Amazon River floodplain. Molecular Ecology Resources, 9(3), 874-876. doi: 10.1111/j.1755-0998.20 08.02331.x

Souza, F. P., Castro, P. L., Goes, E. S. R., Ribeiro, R. P., Santos, S. C. A., Lima, E. C. S.,... LoperaBarrero, N. M. (2018). Genetic variability of Prochilodus lineatus in artificial and semi-natural reproduction. Italian Journal of Animal Science, 17(2), 321-325. doi: 10.1080/1828051X.2017.1365312 